\title{
Tempe and Mineral Availability
}

\author{
Nakamichi Watanabe \\ Showa Women's University \\ Japan
}

\section{Introduction}

Calcium plays crucial roles in the formation of bones and teeth, cell growth, and metabolism. However, the rate of absorption of calcium in the small intestine and its bioavailability is low, because it can easily crystallize, insolubilize, and precipitate at the physiological $\mathrm{pH}$. Therefore, despite that calcium plays many crucial roles in development and other process, the bioavailability of this essential mineral tends to be scarce.

Certain food ingredients, such as casein phosphopeptides (CPPs) and nondigestible oligosaccharides, are known to improve the absorption of calcium by preventing its crystallization in the small intestine.

Tempe, which is produced by the fermentation of boiled soybean by means of Rhizopus culture, is a traditional soyfood in Indonesia. Soyfoods are generally considered an unfavorable source of calcium because soybean is rich in phytate that chelates calcium and retards its absorption. However, the phytate content in tempe is established to be less than half of that in soybean. Accordingly, it is expected that the consumption of tempe may in contrast improve the absorption of calcium from the small intestine.

In this chapter, I first emphasize the importance of dietary calcium and the problems associated with calcium deficiency. Second, I discuss an animal study that, which our group conducted to assess the effect of soybean fermentation on calcium absorption in growing male rats. It was found that the calcium absorption ratio of the rats fed tempe was significantly higher than that of the rats fed unfermented soybean. The high calcium absorption ratio of the tempe group may have been caused by both low phytate content and peptides that were produced during the fermentation of soybean by Rhizopus. This section also describes other components such as CPPs, which improve the availability of calcium. Third, I describe the results of my in vitro study; in particular, I discuss the ability of minerals, such as calcium and nonheme iron, to solublilize in the presence of phytate. It was determined that the solubilization of nonheme iron was affected by the concentration of phytate, whereas that of calcium was not. Finally, I present the potential challenges and future possibilities in this area.

\section{The roles of calcium and absorption}

Dietary calcium plays crucial roles in the formation of bones and teeth, contraction of muscles, activation of enzymes, secretion of hormones, and various functions of the cell, including excitation of nerves and aggregation of blood. Dietary calcium is absorbed by, not only the upper gastrointestinal tract including the duodenum, but also by the jejunum and 
ileum. However, generally the rate of absorption of calcium from the small intestine and the bioavailability of calcium have been reported to be low because calcium easily crystallizes, insolubilizes, and precipitates at the physiological pH (Saito and Lee, 1998; Heuvel et al., 1999) Accoringly, at present, calcium is the sole mineral that is deficient in the Japanese diet according to the latest nutrition survey.

\section{The ingredients in food that affect calcium absorption}

The ingredients in food that affect calcium absorption are shown in Table 1 (Uenishi, 2001). In this section, I describe CPPs and phytate in more detail.

CPPs, the components made by digestions of milk casein, are suggested to increase the passive transport of calcium in the small intestine by preventing its crystallization due to the phosphorylated serine residues in the CPP molecule (Saito and Lee, 1998). However, it has also been reported that the preferable effect of CPP is affected by its concentration and the existence of dietary fiber (Hansen et al., 1997; Bennett et al., 2000).

Phytate (inositol-6-phosphate) interacts with calcium strongly and forms the phytate salt of calcium at a molar ratio from 1:1 to 1:6. Because the salt is water-insoluble at a high molar ratio and our gastrointestinal tract lacks phytase, which is the enzyme that digests phytate, we cannot utilize the insoluble calcium salt (Zhou \& Erdman, 1995). Soyfoods are generally considered an unfavorable source of calcium supply because soybean is rich in phytate that retards the absorption of calcium (Anderson and Wolf, 1995), although, soybean has a relatively high contents of calcium.

\begin{tabular}{|c|c|}
\hline Accelerate & Suppress \\
\hline Casein phosphopeptide (CPP) & Phytate \\
\hline Lactate & Oxalate \\
\hline Oligosaccharide & Dietary fiber \\
\hline Vitamin D & Excessive phosphorus \\
\hline Lysin & Saturated fatty acid \\
\hline Arginin & \\
\hline n-3 Polyunsaturated fatty acids & \\
\hline Materials that accelate gastric acid & \\
\hline
\end{tabular}

Table 1. Food ingredients that affect calcium absorption.

\section{Tempe}

Tempe, the traditional soy-fermented soyfood prepared by salt-free fermentation with Rhizopus microsporus, was originally developed in Central Java, Indonesia. Because there are some kinds of tempe made from ingredients other than whole soybean, both traditional tempe and a couple other types are shown in Fig. 1. Tempe made from soybeans is rich in not only soy protein, glycosidized isoflavones, and vitamin B, all of which are originally present in soybean, but also in free amino acids and isoflavone-aglycones that are produced during the fermentation process (Karyadi and Lukito, 1996; Ikeda et. al., 1999). Therefore, tempe intake has been reported to decrease the effects of chronic degenerative diseases, 
including cancer, coronary disease, osteoporosis, and menopausal symptoms, due to its high antioxidative activity (Watanabe et. al., 2007) and the decreasing effects of plasma lowdensity lipoprotein (LDL) levels (Nout and Kiers, 2004).

Moreover, it has also been reported that the phytate content in tempe decreases to less than half of that present in soybeans, due to phytase during fermentation (Mugula, 1992). Moreover, in an in vitro experiment, it has been reported that calcium precipitation was drastically decreased in tempe compared with that in unfermented soybean, mainly due to the presence of peptides with molecular weight of 10,000 or more in tempe (Japan patent, JP 2004-57204 A.). Therefore, it was expected that an improvement in calcium absorption would occur by fermentation of soybean during tempe processing.
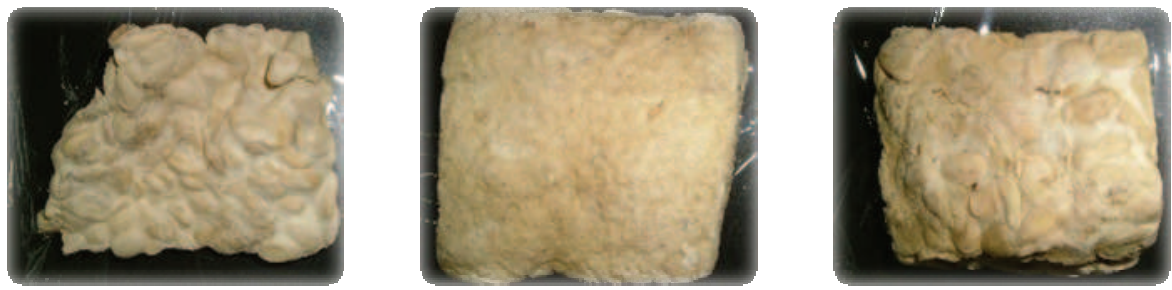

Fig. 1. Photos of different kinds of tempe made from (a) soybean, (b) okara, and (c) kapok. Okara is soybean fiber that remain after making tofu. Kapok is a deciduous tree.

\section{Dietary tempe and calcium absorption.}

In this section, I describe the results of an animal study that examined the effect of dietary tempe on calcium absorption (Watanabe et. al., 2008).

\subsection{Experimental procedure}

Three-week-old male Sprague-Dawley rats were purchased from Japan SLC, Inc. (Shizuoka, Japan). The animals were housed individually in stainless steel cages at room temperature $\left(20-25^{\circ} \mathrm{C}\right)$ with a $12 \mathrm{~h} \mathrm{light/dark} \mathrm{cycle} \mathrm{(light} \mathrm{from} \mathrm{8:00} \mathrm{to} \mathrm{20:00).} \mathrm{They} \mathrm{were} \mathrm{fed} \mathrm{a} \mathrm{commercial,}$ nonpurified chow diet (F-2; Funabashi Farms, Chiba, Japan) for a week. The animals were subsequently grouped into 3 dietary groups, consisting of 5 rats per group, and they were fed the indicated experimental diets for 4 weeks.

The experimental diets were formulated based on the AIN-93G specifications. Soybean, conventional tempe, and anaerobic-tempe were used as the protein sources of the experimental diets. Conventional tempe and anaerobic-tempe were prepared as previously described (Aoki et al., 2003). Briefly, steamed soybeans were incubated aerobically with $R$. microsporus IFO 32002 for $20 \mathrm{~h}$ (to obtain conventional tempe), and then anaerobically incubated for $5 \mathrm{~h}$ (to obtain anaerobic-tempe).

The calcium and phosphorus levels were adjusted by addition of $\mathrm{CaCO}_{3}$ and $\mathrm{K}_{2} \mathrm{HPO}_{4}$, respectively. The magnesium level of the diet was not adjusted. The calcium contents of soybean, tempe, and anaerobic-tempe were $6.1,5.9$, and $6.1 \mathrm{~g} / \mathrm{kg}$, respectively. The magnesium contents were 1.4, 1.1, and $0.9 \mathrm{~g} / \mathrm{kg}$, respectively. Furthermore, the phosphorus contents were $4.5,4.1$, and $4.3 \mathrm{~g} / \mathrm{kg}$, respectively. 
All animals received daily-prepared fresh diets ad libitum for 4 weeks. The rats were housed in metabolic cages for 3 days before the end of this test period, and the feces and urine were collected from each rat. An $\mathrm{HCl}$ solution $(1 \mathrm{~mol} / \mathrm{L})$ was added to each flask for collecting urine. The apparent mineral absorption ratio was calculated using the following formula: apparent absorption ratio $=($ intake - fecal excretion - urinary excretion $) /$ intake $\times 100$.

At the end of the 4-weeks test period, the rats were sacrificed by decapitation under diethyl ether anesthesia. Their blood was collected and centrifuged at $1700 \times \mathrm{g}$ for $10 \mathrm{~min}$ to separate the plasma.

\subsection{Results and discussion}

The results of the calcium balance tests for 3 consecutive days are shown in Fig. 2. The group order based on the calcium absorption ratio for the 3 days tested was as follows: tempe group $>$ anaerobic-tempe group $>$ soybean group. In particular, the absorption ratio of the tempe group was higher than those of the other 2 groups, although no significant difference was observed between the groups on the third day. Furthermore, no significant differences were found in the calcium contents in the femur and plasma samples among the dietary groups (data not shown).

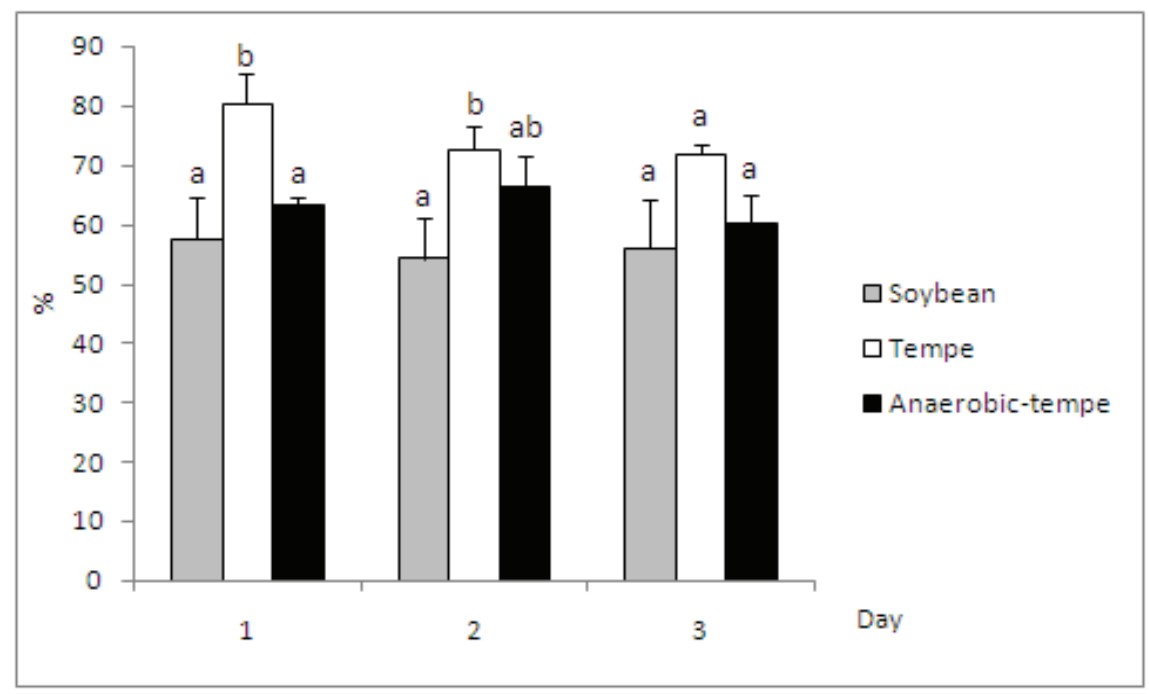

Fig. 2. Calcium absorption ratio of 5 rats (means \pm SE.) from each of the soybean, tempe, and anaerobic-tempe groups through the 3 days before the end of the test period. The different letters on top of the bars indicate significant differences among groups on each day $(\mathrm{p}<$ 0.05).

Despite that the occurrence of CPP-like peptides are not expected in fermented soy products, some peptides that prevent the crystallization of calcium and promote its absorption, such as peptides rich in acidic amino acids (Muramoto et al., 1994), may be 
produced during fermentation. The calcium absorption ratio of the anaerobic-tempe group was remarkably less than that of the tempe group. Therefore, the effective peptides in the tempe may be hydrolyzed during anaerobic fermentation because, as previously reported, the contents of free amino acids and oligopeptides increases considerably during anaerobic fermentation carried out to produce anaerobic-tempe (Watanabe et al., 2006).

The phytate contents in soybean, tempe, and anaerobic-tempe were 18.4, 13.4, and 1.60 $\mathrm{g} / \mathrm{kg}$, respectively. The particularly low level of phytate in the anaerobic-tempe may be due to the hydrolysis of phytate during anaerobic fermentation (Sutardi and Buckle, 1988). However, since a reverse correlation was not observed between calcium absorption and phytate content, the effect of phytate on calcium absorption was determined to be restricted. Isoflavones in soyfoods were also reported to enhance calcium absorption in rats (Zafer \& Weaver, 2004). The isoflavone content of unfermented soybean was the highest among the 3 experimental soyfoods in this study; both the tempe and anaerobic-tempe showed identical isoflavone content (data not shown). Therefore, isoflavones may not be the major factor responsible for the high calcium absorption ratio of the tempe group observed in this study. The absorption ratios of magnesium in each of the diet groups are shown in Fig. 3. In contrast with the calcium absorption results, the magnesium absorption ratio of the tempe group was lower than those of the other 2 groups, although no significant difference was observed on the second day.

The absorption ratios of phosphorus for each of the diet groups are shown in Fig. 4. Similar to the magnesium absorption results, the phosphorus absorption ratio of the tempe group was lower than those of the other 2 groups, although a significant difference was observed only on the third day.

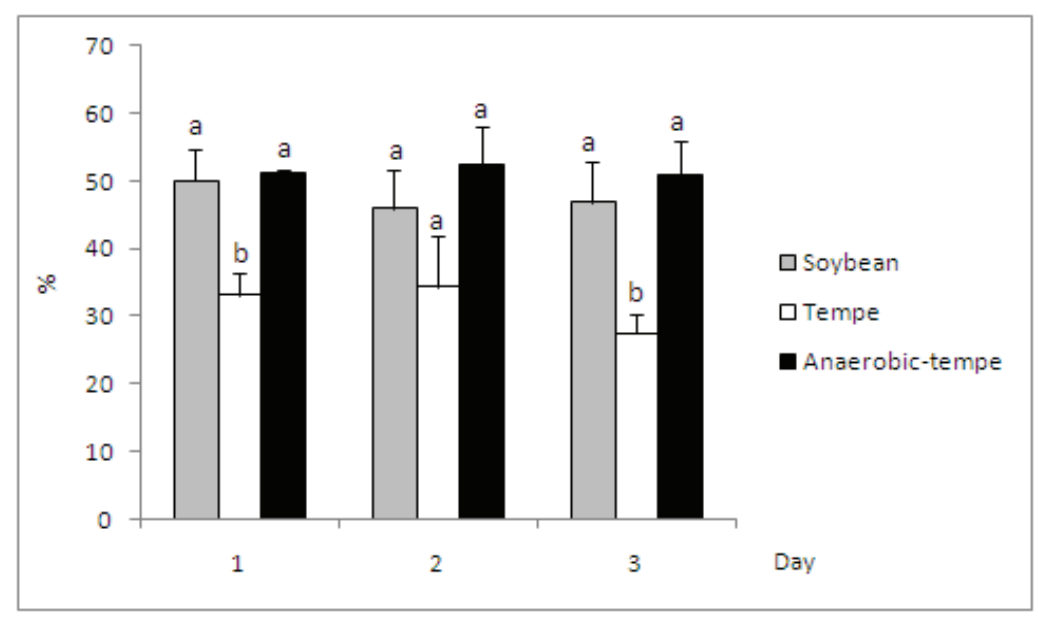

Fig. 3. Magnesium absorption ratio of 5 rats (means \pm SE) from the soybean, tempe, and anaerobic tempe groups during the 3 days before the end of the test period. The different letters above the bars indicate significant differences among the groups on each day $(\mathrm{p}<$ $0.05)$. 


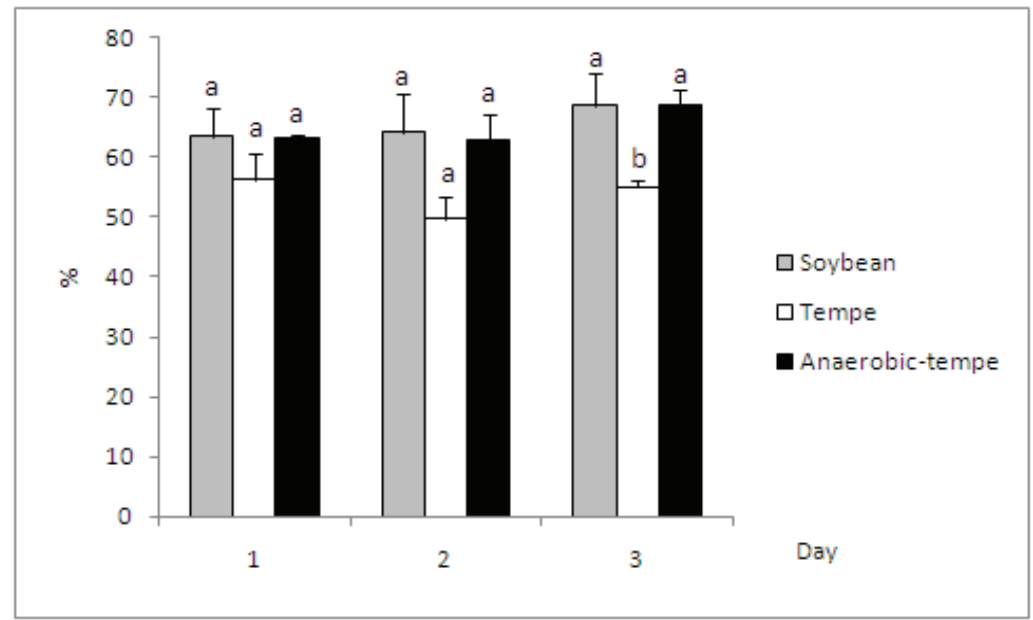

Fig. 4. Phosphorus absorption ratio of 5 rats (means \pm SE) from the soybean, tempe, and anaerobic tempe groups during the 3 days before the end of the test period. The different letters above the bars indicate significant differences among the groups on each day $(\mathrm{p}<$ $0.05)$.

\section{Phytate contents and calcium solubility}

Because the effect of phytate on calcium absorption was found to be restricted in our animal study, as described in section 5, I also describe the results of an in vitro calcium solubility assay using some kinds of soyfoods, including tempe, in this section.

\subsection{Experimental procedure}

Two kinds of unfermented soybean, 5 kinds of Japanese tempe, and 5 kinds of Indonesian tempe were used. All of these soyfoods were freeze-dried and then powdered. The powders were subsequently used as the experimental samples in the calcium solubility assay.

Fifty milligrams of each powdered experimental sample, $100 \mu \mathrm{L}$ of $20 \mathrm{mM}$ calcium chloride solution, and $20 \mathrm{mM}$ phosphate buffer ( $\mathrm{pH} 7.0$ ) were mixed and then incubated for $30 \mathrm{~min}$ at $37{ }^{\circ} \mathrm{C}$. Each mixture was centrifuged for $10 \mathrm{~min}$ at $9100 \times \mathrm{g}$, and then the calcium concentration of the supernatants was measured using Calcium E-test (Wako Pure Chemical Industries, Ltd., Osaka, Japan). A mixture using distilled water instead of $20 \mathrm{mM}$ calcium chloride solution was used as the blank.

\subsection{Results and discussion}

The correlation between calcium solubility and the phytate contents in some kinds of soyfoods is shown in Fig. 5. The longitudinal axis shows the ABS of the experimental solution. A low ABS indicates low solubility of calcium. Because the calculated correlation coefficient was -0.445 , which indicates a weak negative correlation, high phytate contents may induce low calcium solubility in this condition. However, because the correlation coefficient was not particular high, other factors other than phytate are likely also important for solubilizing calcium. 
Furthermore, there are a number of inconsistent studies about the relationship between calcium absorption and phytate content in diet.

One study reported that a diet that consisted of $20 \%$ phytate-free soybean protein increased the calcium absorption ratio by only $1 \%$ in growing male rats, although the magnesium and zinc absorption ratios were increased by $5-10 \%$ compared with a diet of soybean protein and casein (Fukui et al., 1997). In another study that used mature and immature rats, the phytate level did not affect the absorption of calcium (Mason et al., 1993). Furthermore, another study that used infant formulas determined that the phytate level in a diet that contained soybean protein did not affect mineral bioavailability, such as calcium and phosphorus, in rats (Churella, 1989).

In contrast, another report indicated that a diet that consist of $20 \%$ phytate-free soybean protein increased both the absorption and retention ratios of calcium, magnesium, phosphorus, iron, and zinc, compared with a diet of soy protein isolate and casein in rats (Kamao et al., 2000). With the exception of the aforementioned study, other investigatiors have reported an unfavorable effect of phytate on calcium availability (Anderson \& Wolf, 1995; David \& Wolf, 1987).

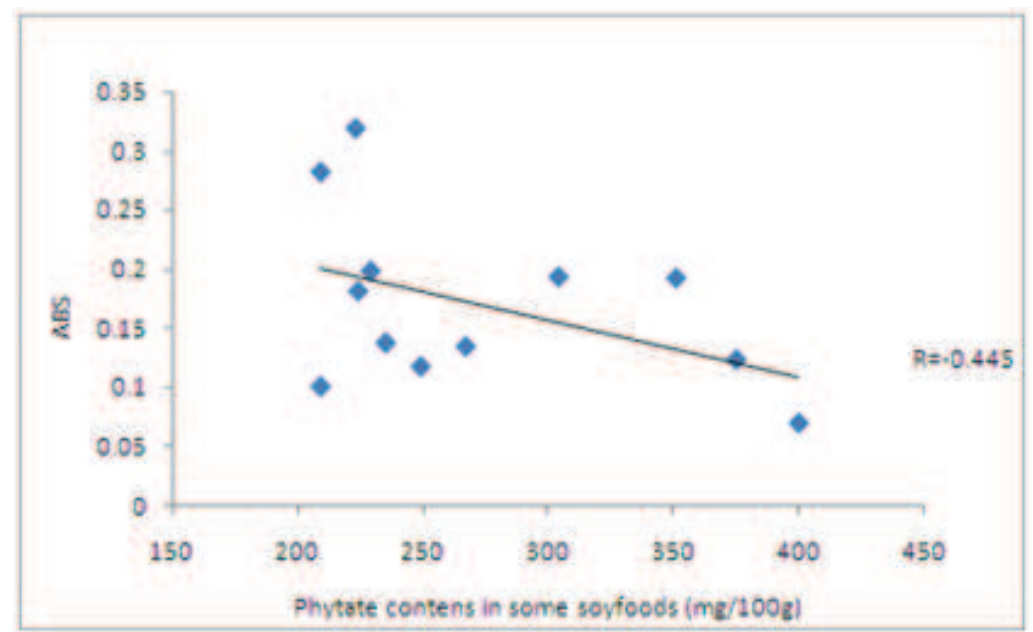

Fig. 5. Correlation between calcium solubility and the phytate content in different kinds of soyfoods. The longitudinal axis shows the ABS of the experimental solutions; A low ABS indicates a low solubility of calcium.

Moreover, the addition of phytate to diets has been demonstrated to decrease the absorption ratios of magnesium and phosphorus, but not calcium (Miyazawa et al., 1996).

\section{Phytate contents and nonheme iron solubility}

In this section, I describe the results of an in vitro nonheme iron solubility assay using some kinds of soyfoods, such as tempe. Nonheme iron reportedly reduced in the stomach and absorbed by the duodenum and proximal jejunum. The absorption ratio of nonheme iron is also low, because the nonheme iron is likely to be crystallized, insolubilized, and precipitated similarly to calcium. The low availability of nonheme iron, which occupies a 
large proportion of a typical diet, is one of the factors that lead to a lack of iron as a nutrient (Clydesdale, 1983).

\subsection{Experimental procedure}

Samples for the nonheme iron solubility assay were prepared by the method described in section 6.1. Furthermore, $50 \mathrm{mg}$ of each powdered experimental sample, $30 \mu \mathrm{L}$ of $\mathrm{FeCl}_{3}$ solution $(1.68 \mathrm{mg} / \mathrm{mL} \mathrm{HCl})$, and $500 \mu \mathrm{L}$ of MOPS buffer $(\mathrm{pH} 7.5)$ were mixed, and subsequently incubated for $30 \mathrm{~min}$ at $37^{\circ} \mathrm{C}$. The mixtures were centrifuged at $9100 \times \mathrm{g}$, and the concentration of the supernatants was measured using Fe C-test (Wako Pure Chemical Industries, Ltd.). A mixture using distilled water instead of $\mathrm{FeCl}_{3}$ solution was used as the blank.

\subsection{Results and discussion}

The correlation between nonheme iron solubility and phytate content in some kinds of soyfoods is shown in Fig. 6. The longitudinal axis shows the ABS of the experimental solutions. A low ABS indicates low solubility of nonheme iron. Because the calculated correlation coefficient was 0.807 , which indicates a strong positive correlation, a high phytate content may induce high nonheme iron solubility in this condition, whereas higher phytate content suggested to induce lower mineral solubility.

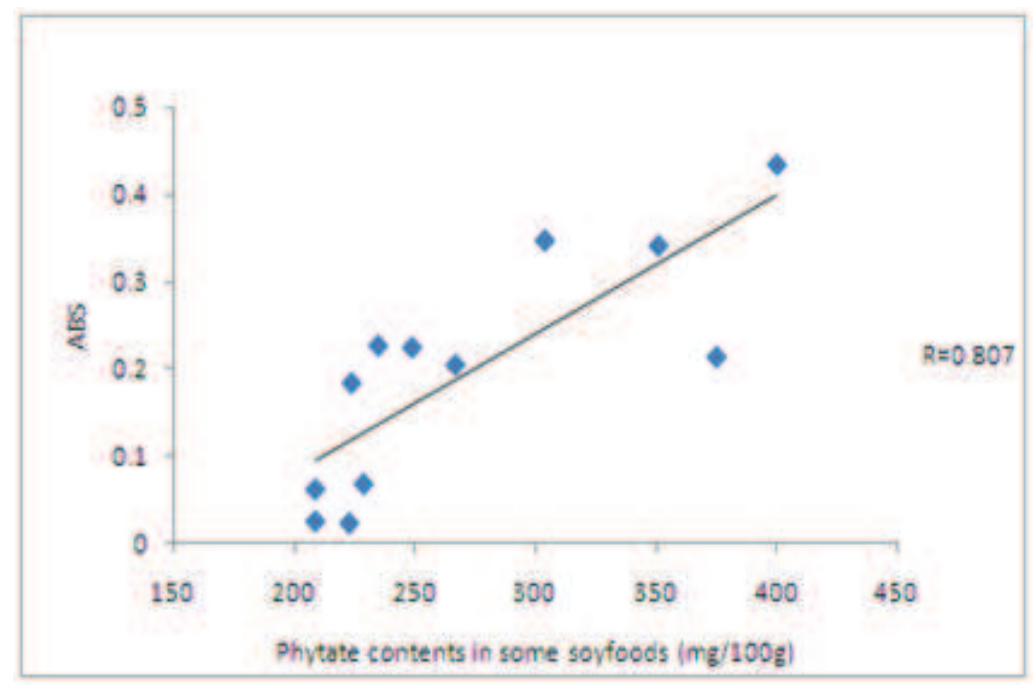

Fig. 6. Correlation between nonheme iron solubility and phytate content in some kinds of soyfoods. The longitudinal axis shows the ABS of the experimental solution; A low ABS indicates low solubility of nonheme iron.

Similar to the existing literature on calcium absorption, there are also some inconsistent studies about the relationship between phytate contents in diets and nonheme iron absorption.

Dietary phytate has been suggested to decrease the bioavailability of iron due to the formation of iron and phytate in the small intestine (Minihane \& Rimbach, 2002). The absorption ratio of iron from bread containing bran was remarkably lower than that from 
white bread. Moreover, the absorption ratio of iron from the bread with bran with removed phytate from an $\mathrm{HCl}$ treatment increased to the same level as from white bread (Hallberg, 1984).

In contrast, although excessive administration of phytate created complexes of phytate with iron and calcium, the absorption ratios of iron and calcium were unaffected (Graf \& Eaton, 1984).

The formation of phytate-iron complexes are suggested to involve either monoferric phytate that complexes with 1 iron, or ferric phytate that complexes with 2 or more irons. While monoferric phytate is contained in wheat, ferric phytate is contained in soybean. Furthermore, the bioavailability of monoferric phytate is high relatively and that of ferric phytate is low (House \& Welch, 1987; Morris \& Ellis, 1976; Ambe et al., 1987).

\section{Conclusion}

As evidence by the findings presented in this chapter, the relationship between phytate concentrations and mineral availability has remained unclear. The relationship between the solubility and both calcium and iron, as determined by the methods in section 5.1 and 6.1, are shown in Figs. 7 and 8, respectively.
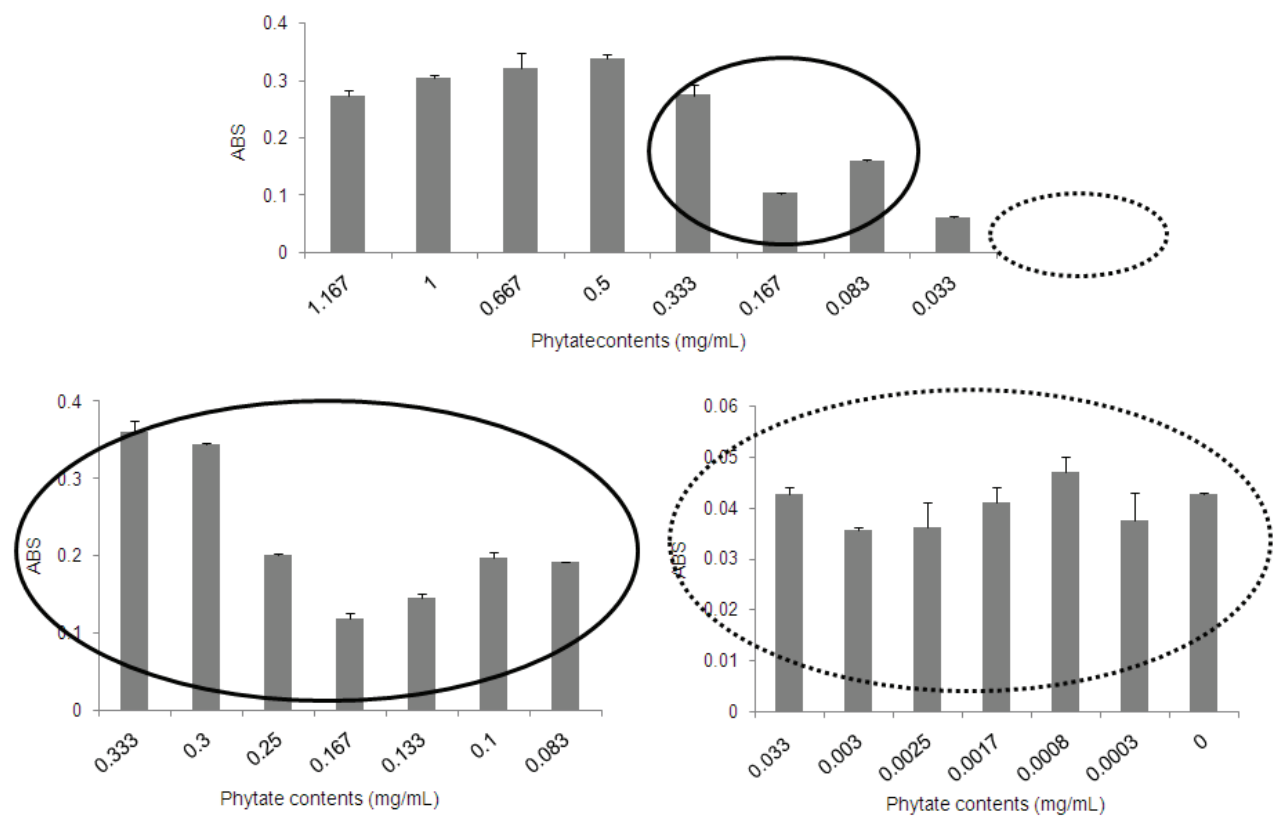

Fig. 7. The relationship between phytate contents and solubility of calcium based on an in vitro assay. The longitudinal axis shows the ABS of the experimental solutions. A low ABS indicates low solubility of calcium. The upper graph panel indicates calcium solubility in a range of phytate contents from $1.167 \mathrm{mg} / \mathrm{mL}$ to $0.033 \mathrm{mg} / \mathrm{mL}$. Furthermore, the left lower panel indicates calcium solubility in the phytate contents of the concentration range shown in the solid line circle on the upper panel. Similarly, the right lower panel indicates the solubility at concentrations in the area shown in the dotted line circle on the upper panel. 


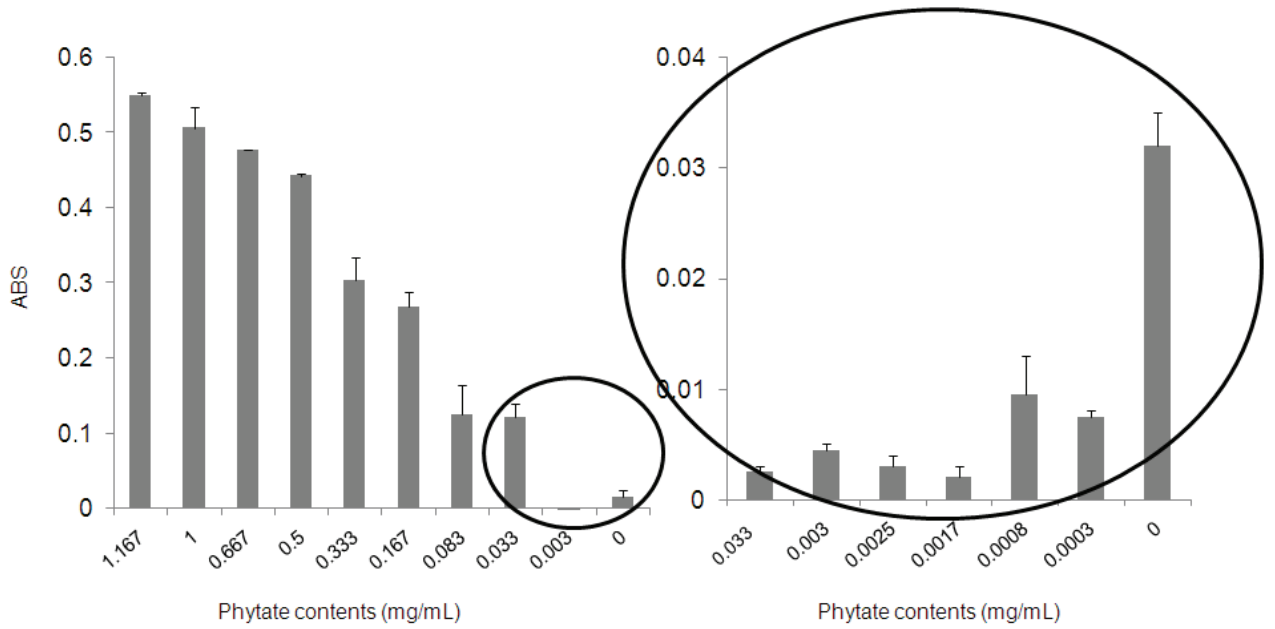

Fig. 8. The relationship between phytate content and solubility of iron based on an in vitro assay. The longitudinal axis shows the ABS of the experimental solutions. A Low ABS indicates low solubility of nonheme iron. The left panel show the iron solubility in the phytate contents ranging from $1.167 \mathrm{mg} / \mathrm{mL}$ to $0 \mathrm{mg} / \mathrm{mL}$. The right panel indicates the iron solubility at concentration shown in the circle on the left panel.

As shown in Fig. 7, calcium solubility is maximized an optimal concentration of phytate. In this study, the optimal concentration of phytate was determined to be $0.167 \mathrm{mg} / \mathrm{mL}$. At the higher and lower phytate concentrations, the solubility was not lower than at the optimal concentration.

As shown in Fig. 8, nonheme iron solubility decreased gradually in the phytate concentration from $1.167 \mathrm{mg} / \mathrm{mL}$ to $0.033 \mathrm{mg} / \mathrm{mL}$. On the other hand, in the concentration lower than $0.033 \mathrm{mg} / \mathrm{mL}$, the solubility in the $0 \mathrm{mg} / \mathrm{mL}$ was the highest.

Despite that I indicated a relationship between phytate concentration and both calcium and nonheme iron solubility, the physiological concentrations of calcium and nonheme iron in the small intestine remain unclear. Therefore, further detailed investigations were needed to elucidate the role of phytate in the solubility, absorption, and bioavailability of minerals such as calcium and nonheme iron.

\section{References}

Ambe, S.; Ambe, F.; Nozaki, T. (1987). Moessbauer study of iron in soybean seeds. J. Agric. Food. Chem., 35, 292-296.

Anderson, R.L. \& Wolf W.J. (1995). Compositional changes in trypsin inhibitors, phytic acid, saponins and isoflavones related to soybean processing. J. Nutr., 125, 581S-588S.

Aoki, H.; Uda, I.; Tagami, K.; Furuya, Y.; Endo, Y. \& Fujimoto, K. (2003). The production of a new tempe-like fermented soybean containing a high level of $\gamma$-aminobutyric acid by anaerobic incubation with Rhizopus. Biosci. Biotechnol. Biochem., 67,1018-23. 
Bennett, T.; Desmond, A.; Harrington, M.; McDonagh, D.; FitzGerald, R.; Flynn, A. \& Cashman, K.D. (2000). The effect of high intakes of casein and casein phosphopeptide on calcium absorption in the rat. Br. J. Nutr., 83, 673-80.

Churella, H.R. (1989). Effects of phytic acid level in soy protein based infant formulas on mineral availability in the rat. J. Agric. Food Chem., 37, 1352-1357.

Clydesdale, F.M. (1983). Physicochemical determinants of iron bioavailability. Food Technol., 37, 133-138.

Fukui, K.; Kuwata, G. \& Imai, M. (1997). Effects of phytate removal from soybean protein on calcium, magnesium and zinc absorption of rats. J. Jpn. Soc. Nutr. Food. Sci., 50, 273278.

Graf, E. \& Eaton, J.W. (1984). Effects of phytate on mineral bioavailability in mice. J. Nutr., $114,1192-1198$.

Hallberg, L. (1984). Betydelsen av kostfiber och fytinsyra foer biotillgaengligheten av jaern. Naeringsforskning, 20, 56-58.

Hansen, M.; Sandström, B.; Jensen, M. \& Sørensen, S.S. (1997). Casein phosphopeptides improve zinc and calcium absorption from rice-based but not from whole-grain infant cereal. J. Pediatr. Gastroenterol. Nutr., 24, 56-62.

Heuvel, van den E.G.; Muys, T.; Dokkum, van W. \& Schaafsma, G. (1999). Oligofructose stimulates calcium absorption in adolescents. Am. J. Clin. Nutr., 69, 544-8.

Honig, D.H. \& Wolf W.J. (1987). Mineral and phytate content and solubility of soybean protein isolates. J. Agric. Food Chem., 35, 583-588.

House, W.A. \& Welch, R.M. (1987). Bioavailability to rats of iron in six varieties of wheat grain intrinsically labeled with radioiron. J. Nutr., 117, 476-480.

Ikeda, R.; Ohta, M. \& Watabe, T. (1995). Changes of isoflavone at various stages of fermentation in defatted soybeans. Nippon Shokuhin Kagaku Kougaku Kaishi, 42, 322327.

Kamao, M.; Tsugawa, N.; Nakagawa, K.; Kawamoto, Y.; Okano, T.; Fukui, K.; Takamatsu, K.; Kuwata, G. \& Imai, M. (2000). Absorption of calcium, magnesium, phosphorus, iron and zinc in growing male rats fed diets containing either phytate-free soybean protein or soybean protein isolate or casein. J. Nutr. Sci. Vitaminol., 46, 34-41.

Karyadi, D. \& Lukito, W. (1996). Beneficial effects of tempe in disease prevention and treatement. Nutr. Rev., 54, S94-98.

Mason, A.; Weaver, C.M.; Kimmel, S. \& Brown R.K. (1993). Effect of soybean phytate content on calcium bioavailability in mature and immature rats. J. Agric. Food Chem., 41, 246-249.

Minihane, A.M. \& Rimbach, G. (2002). Iron absorption and the iron binding and anti-oxidant properties of phytic acid. Int. J. Food Sci. Technol., 37, 741-748.

Miyazawa, E.; Iwabuchi, T. \& Yoshida, T. (1996). Phytate breakdown and apparent absorption of phosphorus, calcium, and magnesium in germfree and conventionalized rats. Nutr. Res., 16, 603-613.

Morris, E.R. \& Ellis, R. (1976). Isolation of monoferric phytate from wheat bran and its biological value as an iron source to the rat. J. Nutr., 106, 753-760.

Mugula, J.K. (1992). The nutritive quality of sorghum-commonbean tempe. Plant Food Hum. Nutr., 42, 247-56. 
Muramoto, K.; Yako, .; Murakami, K.; Odo. \& Kamiya, H. (1994). Inhibition of the growth of calcium carbonate crystals by multiple lectins in the coelomic fluid of the acorn barnacle Megabalanus rosa. Comp. Biochem. Physiol., 107, 401-409.

Nout, M.J.R. \& Kiers, J.L. (2004). Tempe as a functional food. Soybeans as functional foods and ingredients, KeShun Liu, 239-247, AOCS Press,1-893997-33-2, USA.

Saito, Y. \& Lee, Y.S. (1998). Minimum effective dose of casein phosphopeptides (CPP) for enhancement of calcium absorption in growing rats. Int. J. Vitam. Nutr. Res., 68, 33540 .

Sutardi, M. \& Buckle, K.A. (1986). Characterization of extra- and intracellular phytase from Rhizopus oligosporus used in tempe production. Int. J. Food Microbiol., 6, 67-79.

Uenishi, K. (2001) Calcium absorption ratio of some foods. Clinical Calcium, 11, 134-136.

Watanabe, N.; Aoki, H. \& Fujimoto, K. (2008). Fermentation of soybean by Rhizopus promotes the calcium absorption ratio in rats. J. Sci. Food Agri., 88, 2749-2752.

Watanabe, N.; Endo, Y.; Fujimoto, K. \& Aoki, H. (2006). Tempe-like fermented soybean (GABA-tempe) has an effective influence on lipid metabolism in rats. J. Oleo. Sci., 55, 391-396.

Watanabe, N.; Fujimoto, K. \& Aoki, H. (2007). Antioxidant activities of the water-soluble fraction in tempeh-like fermented soybean (GABA-tempeh). Int. J. Food Sci. Nutr., 58, 577-587.

Zafar, T.A. \& Weaver, C.M. (2004). Inuline effects on bioavailability of soy isoflavones and their calcium absorption enhancing ability. J. Agric. Food Chem., 52, 2827-2831.

Zhou, J.R. \& Erdman J.W.JR. (1995). Phytic Acid in Health and Disease. Crit. Rev. Food Sci. Nutr, . 35, 495-508. 


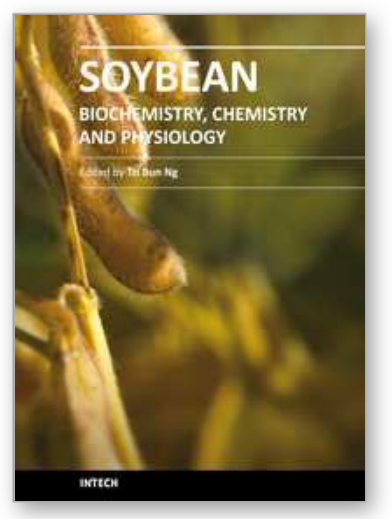

\section{Soybean - Biochemistry, Chemistry and Physiology \\ Edited by Prof. Tzi-Bun Ng}

ISBN 978-953-307-219-7

Hard cover, 642 pages

Publisher InTech

Published online 26, April, 2011

Published in print edition April, 2011

Soybean is an agricultural crop of tremendous economic importance. Soybean and food items derived from it form dietary components of numerous people, especially those living in the Orient. The health benefits of soybean have attracted the attention of nutritionists as well as common people.

\section{How to reference}

In order to correctly reference this scholarly work, feel free to copy and paste the following:

Nakamichi Watanabe (2011). Tempe and Mineral Availability, Soybean - Biochemistry, Chemistry and Physiology, Prof. Tzi-Bun Ng (Ed.), ISBN: 978-953-307-219-7, InTech, Available from:

http://www.intechopen.com/books/soybean-biochemistry-chemistry-and-physiology/tempe-and-mineralavailability

\section{INTECH}

open science | open minds

\section{InTech Europe}

University Campus STeP Ri

Slavka Krautzeka 83/A

51000 Rijeka, Croatia

Phone: +385 (51) 770447

Fax: +385 (51) 686166

www.intechopen.com

\section{InTech China}

Unit 405, Office Block, Hotel Equatorial Shanghai

No.65, Yan An Road (West), Shanghai, 200040, China

中国上海市延安西路65号上海国际贵都大饭店办公楼405单元

Phone: +86-21-62489820

Fax: $+86-21-62489821$ 
(C) 2011 The Author(s). Licensee IntechOpen. This chapter is distributed under the terms of the Creative Commons Attribution-NonCommercialShareAlike-3.0 License, which permits use, distribution and reproduction for non-commercial purposes, provided the original is properly cited and derivative works building on this content are distributed under the same license. 